ISSN 0258-7122

Bangladesh J. Agril. Res. 33(3) : 519-529, December 2008

\title{
GENETIC ANALYSIS OF SALINITY TOLERANCE IN RICE
}

\author{
P. K. SAHA RAY ${ }^{1}$ AND M. AMIRUL ISLAM ${ }^{2}$
}

\begin{abstract}
The genetics of' salinity tolerance in rice was studied by visual scoring in parents $F_{1} F_{2}$ and backcross generations of six crosses. Segregation analysis indicated partial dominance for salinity tolerance. Estimation of genetic parameters under epistatic model indicated the importance of additive effects in the inheritance of salinity tolerance. Highly significant additive type of gene action in Pokkali/BR29 and both additive and dominance type of gene action in Nonabokra/BR29 without interaction were observed suggesting absence of epistasis and validity of additive dominance model. Significant dominance effect of genes in Nonabokra/BR29 suggests the use of hybrid rice where production of hybrid rice seed is feasible. The non-interactions with duplicate type of epistasis were observed in the crosses with moderately tolerant and susceptible parents. As heritability of the trait was low to moderate, the breeding population must he large and selection for tolerance must be exercised in later generations under controlled conditions.
\end{abstract}

Key words: Genetic analysis, salinity, rice.

\section{Introduction}

Rice (Oryza sativa L.) is one of the world's most important cereals for human consumption, providing upto $80 \%$ of the daily energy intake in some Asian countries. However, the rate of increase of rice production is slowing down and if the trend is not reversed, severe food shortages will occur in near future. To meet the food demand, it is necessary to increase rice production either by increasing the yield per unit area or by increasing the cultivated areas. In either way, there are widespread soil problems and salinity that impair normal growth and limits the realization of yield potential of modern rice varieties (Greenland, 1984).

Alleviation of saline soil through various methods, such as reclamation, irrigation and drainage are not always economical or practical. Breeding for salt tolerance offers more promising, energy efficient, economical, and socially acceptable approach to solving these problems than that of other processes of soil amelioration. The acquisition of the character of salt tolerance in modern rice offers the hope of increasing rice yield on current saline lands and bringing million of hectares idle lands in rice production without costly input that can help improve socio-economic conditions of salt affected areas in developing countries.

${ }^{1}$ Chief Scientific Officer \& Head, BRRI Regional Office, Comilla, ${ }^{2}$ Professor, Department of Genetics and Plant Breeding, BAU, Mymensingh, Bangladesh. 
Gregorio and Senadhira (1993) reported the clear relation of low Na-K ratio to salinity tolerance. Na-K ratio in shoot is also the best indicator of grain yield (Gill and Singh, 1995). Moreover, Na-K ratio is related to visual score (Lee and Senadhira, 1996). The score based on visual symptoms related well to grain yield and yield reduction due to salt stress (Gregorio et al., 1997). This shows the reliability of visual scoring for salinity screening. Breeding research on salinity tolerance in rice has gained importance only recently with these developments. However, studies on the genetics of salinity tolerance in rice have been limited, inhibiting the realization of breeder's goal. This study was undertaken to understand genetic architecture of salinity tolerance score by partitioning genetic means and also by segregation analysis. The information ill be helpful in designing breeding work to develop modern rice varieties with higher ability to cope with salt stress.

\section{Materials and Method}

Seven rice varieties that differed in their tolerance to salinity (2 tolerant, 4 moderately tolerant and susceptible) ere used as parents in this study (Table 1). The varieties tolerant selected from a preliminary germplasm screening conducted by the authors at the seedling stage. Salinity tolerant (Pokkali and Nonabokra) and moderately tolerant (Nonasail, Rajasail, Binnatoa and Purbachi) varieties were used as female parents $\left(\mathrm{P}_{1}\right)$, while susceptible variety BR29 was used as pollen parent $\left(\mathrm{P}_{2}\right)$. $\mathrm{F}_{1}$ seeds of six crosses and their parents were planted in the net house to generate new $F_{1}, F_{2}, B_{1}$ and $B_{2}$ generations for use in the analysis of segregation and the estimation of genetic parameters.

Table 1. Seeding height and tolerance parameters of parental varieties of rice.

\begin{tabular}{|c|c|c|c|c|c|c|}
\hline \multirow[t]{2}{*}{ Variety } & \multirow{2}{*}{$\begin{array}{l}\text { Seeding } \\
\text { height } \\
\text { (cm) }\end{array}$} & \multicolumn{4}{|c|}{ Tolerance Parameters } & \multirow{2}{*}{$\begin{array}{l}\text { Degree } \\
\text { of } \\
\text { tolerance }\end{array}$} \\
\hline & & $\begin{array}{l}\text { Visual } \\
\text { score }\end{array}$ & $\begin{array}{c}\text { Shoot } \\
\mathrm{Na}^{+}\end{array}$ & $\begin{array}{c}\text { Shoot } \\
\mathrm{K}+\end{array}$ & $\begin{array}{l}\mathrm{Na} / \mathrm{K} \\
\text { ratio }\end{array}$ & \\
\hline 1. Pokkali & 54 & 3.7 & 2.59 & 3.31 & 0.78 & $\mathrm{~T}$ \\
\hline 2. Nonabokra & 63 & 4.0 & 2.74 & 3.29 & 0.83 & $\mathrm{~T}$ \\
\hline 3. Nonasail & 53 & 6.4 & 3.32 & 2.04 & 1.63 & MT \\
\hline 4. Rajasail & 59 & 5.6 & 2.64 & 2.34 & 1.13 & MT \\
\hline 5. Binnatoa & 54 & 5.5 & 3.11 & 2.72 & 1.14 & MT \\
\hline 6. Purbachi & 31 & 6.0 & 3.22 & 1.83 & 1.76 & MT \\
\hline 7. BR29 & 30 & 8.2 & 3.64 & 1.37 & 2.66 & $\mathrm{~S}$ \\
\hline
\end{tabular}

$\mathrm{T}=$ Tolerant $\quad \mathrm{MT}=$ moderately tolerant $\quad \mathrm{S}=$ Susceptible 
The experiment as conducted in small plastic cups $(7 \times 6 \mathrm{~cm})$ with two circles of pinholes $2 \mathrm{~cm}$ apart on the wall. The topmost circle of the hole was 2 $\mathrm{cm}$ below the rim of the cup. The cups were filled with soil from previously grown rice field of BRRI upto $1 \mathrm{~cm}$ above the topmost circle of holes and placed in large plastic trays containing water. The water level was kept same as the soil level. While maintaing the water level, extra soil was added after a day or two as the soil began to settle after absorbing water. All six generations $\left(\mathrm{P}_{1}, \mathrm{P}_{2}, \mathrm{~F}_{1}, \mathrm{~F}_{2}\right.$, $B_{1}$ and $B_{2}$ ) in each combination were grown on a single tray.

Fifteen pre-germinated seeds of each cross and their parents were placed on soil surface in each cup. One week after seeding, seedlings were thinned to ten per cup and the water level vas raised $1 \mathrm{~cm}$ above the soil and maintained this level daily. When the seedlings were 15 days old, the water in the plastic tray was removed by siphoning. After 12 hours, the remaining water that drained out from the cups was also removed. Then the plastic tray was filled up with $\mathrm{NaCI}$ solution (ECw 9.0-9.5 dS/m) upto $1 \mathrm{~cm}$ above soil surface. This level of conductivity (EC) was monitored every day using an EC meter and adjusted as necessary by adding tap water. Salinity symptoms of each plant from the parental varieties along with population of $F_{1}, F_{2}, B_{1}$, and $B_{2}$ of each cross were scored visually (1 to 9 ) using the modified standard evaluation system of IRRI (Gregorio et al., 1997) after 20 days of' salinization when plants of susceptible check BR29 were severely affected. The entries were classified for their reaction to salinity as tolerant (score 3.0-4.9), moderatey tolerant (score 5.0-6.9) and susceptible (score 7.0-9.0).

Means $(\overline{\mathrm{X}})$ variances $(\mathrm{Vx})$, variances of the mean $\left(\mathrm{V}_{\overline{\mathrm{X}}}\right)$, standard error of the mean $\left(\mathrm{SN}_{\overline{\mathrm{X}}}\right)$, and coefficient of variation (CV \%) or salinity tolerance score were computed for different genetic populations. Scaling test as per Mather \& Jinks (1971) and the Joint scaling test of Cavalli (1952) were carried out to test the adequacy of the additive-dominance model. The digenic or six parameter epistatic model of Hayman (1958) as used to partition generation means with different genetic effects. Estimate of broad sense heritability was computed with the formula described by Allard (1960).

\section{Growth conditions}

This experiment was conducted at the Bangladesh Rice Research Institute (BRRI), Gazipur in the net house without an environmental control, having glass covered roof, sides open having only wire gauze and there vas no problem for sunlight. Inside the net house, the ranges of maximum and minimum temperatures were 21.5 to $32.1^{\circ} \mathrm{C}$, and 15.9 to $23.2^{\circ} \mathrm{C}$, respectively. The maximum relative humidity ranged from 70 to $95 \%$. The solar radiation was 204.8 to $369.5 \mathrm{cal} / \mathrm{cm}^{2}$ day. 


\section{Results and Discussion}

\section{Segregation analysis}

The mean salinity tolerance score of the $\mathrm{F}_{1} \mathrm{~s}$ of Pokkali/BR29, Nonabokra/BR29 Rajasail/BR29, Binnatoa/BR29 and Purbachi/BR29 were between the mid-parent value and the tolerant parents $\left(\mathrm{P}_{1}\right)$ (Table 2 ), suggesting that dominant genes controlled salinity tolerance. However, the mean score of $F_{1} S$ of the cross Nonasail/BR29 fell between the mid-parent and the susceptible parent $\left(\mathrm{P}_{2}\right)$. This indicated the recessiveness of this trait. Low mean score in $\mathrm{B}_{1}$ compared to $\mathrm{B}_{2}$ in the crosses and low variance in $\mathrm{B}_{1}$ compared to $\mathrm{B}_{2}$ in Pokkali/BR29. Nonabokra/BR29 and Purbachi/BR29 further attested dominance gene action of salinity tolerance (Table 3). However, the potence ratio of Pokkali/BR29. Nonabokra/BR29 and Binnatoa/BR29 indicated that salinity tolerance was partially dominant (Table 2). The potence ratio of Nonasail/BR29 indicated small decree of partial dominance. The potence ratio of Rajasail/13R29 and Purbachi/BR29 indicated complete dominance of salinity tolerance. Partial dominance of salinity tolerence is the best overall conclusion as indicated by four crosses out of six. Jones (1985) determined salinity tolerance of rice by tolerance ratio of root growth in $F_{1}, F_{2}$ and backcrosses and found some evidence of dominance of salinity tolerance.

Table 2. Comparison among mean salinity tolerant scores of parents and $F_{1}$ hybrids and potence ratio in six crosses of rice.

\begin{tabular}{lllllllll}
\hline Cross & $\mathrm{P}_{1}$ & $\mathrm{P}_{2}$ & $\mathrm{MP}$ & $\mathrm{F}_{1}$ & $\mathrm{~h}_{\mathrm{p}}$ & Dominance effect \\
\hline Pokkali/BR29 & 3.83 & 7.90 & 5.88 & 4.60 & 0.63 & Partial dominance \\
Nonabokra/BR29 & 4.25 & 7.90 & 6.08 & 4.84 & 0.68 & Partial dominance \\
Nonasail/BR29 & 5.80 & 7.85 & 6.83 & 6.94 & -0.11 & $\begin{array}{l}\text { Small degree of Partial } \\
\text { dominance }\end{array}$ \\
& & & & & & \\
Rajasail/BR29 & 5.60 & 7.75 & 6.68 & 5.70 & 0.90 & Complete dominance \\
Binnatoa/BR29 & 5.20 & 7.95 & 6.58 & 5.92 & 0.48 & Partial dominance \\
Purbachi/BR29 & 6.00 & 7.75 & 6.88 & 6.04 & 0.95 & Complete dominance \\
\hline
\end{tabular}

\section{Generation mean analysis}

The observed values of all the generation means along ith standard error, variances, variances of the mean, the number of plants on which the means and variances were based and coefficient of variation are shown in Table 3. It was possible to assess whether the variation observed in the generation means can be explained on an additive-dominance basis or whether the interaction between genes at different loci was important. This as achieved by using the scaling test 
developed by Malher and Jinks (1971) and Joint scaling test of Cavalli (1952) for the detection of non-allelic interaction.

Table 3. Generation mean $(\bar{X})$ along with standard error (SE $\bar{X})$, no. of plants, Variance $(\mathrm{Vx})$, variance of the mean $\left(\mathrm{V}_{\overline{\mathrm{X}}}\right)$ and coefficent of variation (CV \% for salinity tolerance score in six crosses of rice.

\begin{tabular}{|c|c|c|c|c|c|}
\hline $\begin{array}{c}\text { Parents and } \\
\text { generation }\end{array}$ & $\begin{array}{c}\text { Mean }(X) \pm \\
(S E \bar{X})\end{array}$ & No. of plants & $\begin{array}{c}\text { Variance } \\
(\mathrm{Vx})\end{array}$ & $\begin{array}{l}\text { Variance of } \\
\text { mean }\left(\mathrm{V}_{\overline{\mathrm{x}}}\right)\end{array}$ & CV (\%) \\
\hline Pokkali & $3.85 \pm 0.16$ & 40 & 1.00 & 0.025 & 26.00 \\
\hline BR29 & $7.90 \pm 0.16$ & 40 & 1.02 & 0.025 & 12.76 \\
\hline $\mathrm{F}_{1}$ & $4.60 \pm 0.21$ & 50 & 2.29 & 0.044 & 32.86 \\
\hline $\mathrm{F}_{2}$ & $5.15 \pm \mathrm{D} .11$ & 271 & 3.13 & 0.012 & 34.33 \\
\hline $\mathrm{B}_{1}$ & $4.51 \pm 0.21$ & 70 & 3.18 & 0.044 & 39.50 \\
\hline $\mathrm{B}_{2}$ & $622 \pm 026$ & 70 & 4.67 & 0.067 & 34.70 \\
\hline NonaBokra & $4.25 \pm 0.16$ & 40 & 0.96 & 0.025 & 23.07 \\
\hline BR29 & $7.90 \pm 0.16$ & 40 & 1.02 & 0.025 & 12.76 \\
\hline $\mathrm{F}_{1}$ & $4.84 \pm 0.23$ & 50 & 2.75 & 0.053 & 34.26 \\
\hline $\mathrm{F}_{2}$ & $5.45 \pm 0.13$ & 220 & 3.85 & 0.017 & 35.96 \\
\hline $\mathrm{B}_{1}$ & $4.40 \pm 0.21$ & 70 & 3.06 & 0.044 & 39.72 \\
\hline $\mathrm{B}_{2}$ & $6.14 \pm 0.25$ & 70 & 4.47 & 0.062 & 34.47 \\
\hline Nonasail & $5.80 \pm 0.21$ & 40 & 1.81 & 0.044 & 23.16 \\
\hline BR29 & $7.85 \pm 0.16$ & 40 & 1.00 & 0.025 & 12.76 \\
\hline $\mathrm{F}_{1}$ & $6.94 \pm 0.19$ & 70 & 2.43 & 0.036 & 22.46 \\
\hline $\mathrm{F}_{2}$ & $7.36 \pm 0.11$ & 283 & 3.58 & 0.012 & 25.68 \\
\hline $\mathrm{B}_{1}$ & $6.15 \pm 0.17$ & 76 & 2.16 & 0.029 & 23.87 \\
\hline $\mathrm{B}_{2}$ & $8.04 \pm 0.14$ & 50 & 1.02 & 0.019 & 12.55 \\
\hline Rajasail & $5.60 \pm 0.21$ & 40 & 1.68 & 0.044 & 23.16 \\
\hline BR29 & $7.75 \pm 0.15$ & 40 & 0.96 & 0.022 & 12.65 \\
\hline $\mathrm{F}_{1}$ & $5.72 \pm 0.27$ & 50 & 3.72 & 0.072 & 33.70 \\
\hline $\mathrm{F}_{2}$ & $6.36 \pm 0.11$ & 278 & 3.16 & 0.012 & 27.93 \\
\hline $\mathrm{B}_{1}$ & $6.17 \pm 0.27$ & 70 & 4.93 & 0.073 & 35.97 \\
\hline $\mathrm{B}_{2}$ & $736 \pm 022$ & 70 & 3.66 & 0.048 & 25.96 \\
\hline Binnatoa & $5.20 \pm 0.17$ & 40 & 1.18 & 0.023 & 2098 \\
\hline BR29 & $7.95 \pm 0.16$ & 40 & 1.02 & 0.025 & 12.72 \\
\hline $\mathrm{F}_{1}$ & $5.92 \pm 0.28$ & 50 & 3.95 & 0.078 & 33.58 \\
\hline $\mathrm{F}_{2}$ & $5.80 \pm 0.12$ & 276 & 3.99 & 0.014 & 34.42 \\
\hline $\mathrm{B}_{1}$ & $5.78 \pm 0.28$ & 84 & 6.74 & 0.078 & 44.90 \\
\hline $\mathrm{B}_{2}$ & $6.84 \pm 0.22$ & 90 & 4.25 & 0.048 & 30.10 \\
\hline Purbachi & $6.00 \pm 021$ & 40 & 1.85 & 0.044 & 22.65 \\
\hline BR29 & $7.75 \pm 0.16$ & 40 & 0.98 & 0.025 & 12.68 \\
\hline $\mathrm{F}_{1}$ & $6.04 \pm 0.29$ & 50 & 4.28 & 0.084 & 34.27 \\
\hline $\mathrm{F}_{2}$ & $6.64 \pm 0.10$ & 330 & 3.60 & 0.010 & 28.58 \\
\hline $\mathrm{B}_{1}$ & $6.23 \pm 0.24$ & 70 & 3.98 & 0.057 & 32.03 \\
\hline $\mathrm{B}_{2}$ & $6.37 \pm 0.26$ & 70 & 4.58 & 0.067 & 33.61 \\
\hline
\end{tabular}


The scaling tests for the additive-dominance model indicated the absence of nonallelic interaction in the crosses Pokkali/BR29, Nona Bokra/BR29 and Purbachi/BR29 as A, B and C were not significant (Table 4). However, in the cross Nonasail/BR29, B and C values were highly significant, but the value of A was not significant. Similarly, in Rajasail/BR29 and Binnatoa/BR29, only B and $\mathrm{C}$ values were significant, respectvely. If one or more of these values deviate significantly from zero, presence of epistasis is indicated for the trait concerned.

Table 4. Values of scaling tests for salinity tolerance scores in six crosses of rice.

\begin{tabular}{lllll}
\hline Cross & Parameters & Values S.E. & T-Values \\
\hline Pokkali/BR29 & A & $0.57 \pm 0496$ & 1.14 \\
& B & $-0.06 \pm 0583$ & 0.10 \\
NonaBokra/BR29 & C & A & $-0.35 \pm 0.648$ & 0.54 \\
& B & $-0.29 \pm 0.504$ & 0.58 \\
& C & $-046 \pm 0.573$ & 0.80 \\
Nonasail/BR29 & A & $-0.03 \pm 0.730$ & 0.04 \\
Rajasail/BR29 & C & $-0.44 \pm 0442$ & 100 \\
& A & $1.29 \pm 0374$ & $345 * *$ \\
Binnatoal BR29 & B & $1.91 \pm 0.638$ & 2.95 \\
& A & $1.02 \pm 0639$ & 1.59 \\
Purbachi!BR29 & B & $1.25 \pm 0.537$ & $2.31 *$ \\
& C & $0.65 \pm 0.742$ & 0.88 \\
& B & $0.44 \pm 0.648$ & 0.67 \\
& C & $-0.19 \pm 0.545$ & 0.34 \\
& $-1.79 \pm 0.773$ & $2.32 *$ \\
\hline
\end{tabular}

* Significant at 5\% level Significant at 1\% level

Mather and Jinks (1971) pointed out some conditions in which one or more of these generation means (i.e., $\mathrm{B}_{1}, \mathrm{~B}_{2}$ and $\mathrm{F}_{2}$ means those referred as $\mathrm{A}, \mathrm{B}$ and $C$ scales) may not deviate significantly from the expected values even when nonallelic infections were present. These conditions are, (a) with a dispersed pair of genes, the three groups of interactions, additive $\mathrm{x}$ additive (i), additive $\mathrm{x}$ dominance (j) and dominance $\mathrm{x}$ dominance (1) interactions ma partly cancel out: and (b) with more than two interacting genes, cancellation can arise because of dispersion and becanse the individual i's, j's and l's may differ from one pair of interacting genes to another. The scaling tests indicated the presence of digenic epistasis in three crosses out of six as one or the other scale was significant.

The main drawback of scaling tests is that out of six populations only three or four are included in the test at a time. To overcome this problem, Joint scaling test of Cavalli (1952) was done as this test permits any combination of the six 
generations at a time. Moreover, Joint scaling test also provides estimates of three genetic parameters, viz., $\mathrm{m}, \mathrm{d}$ and $\mathrm{h}$.

The estimated values of the parameters $\mathrm{m},[\mathrm{d}]$ and $[\mathrm{h}]$ of the joint seal are shown in Table 5. It was observed from the $\mathrm{X}^{2}$ test that the crosses Pokkali/BR29 and Nona Bokra/BR29 fitted well to additive-dominance model. The model failed to fit in the crosses Nonasail/BR29 and Binnatoa/BR29 as X ${ }^{2}$ values of joint scaling test were significant and poorly fitted in the crosses Rajasail/BR29 and Purbachi/BR29. This indicates that simple additive-dominance model was inadequate to explain inheritance of salinity tolerance score in these four crosses.

Table 5. Genetic parameters and $X^{2}$ values of joint scaling test in an additivedominance model for salinity tolerance scores in six crosses of rice.

\begin{tabular}{l|l|l|l|l|l}
\hline \multicolumn{1}{c|}{ Cross } & $\begin{array}{c}\text { Additive } \\
\mathrm{m}\end{array}$ & $\begin{array}{c}\text { dominance } \\
\mathrm{d}\end{array}$ & $\begin{array}{c}\text { model } \\
\mathrm{h}\end{array}$ & \multicolumn{1}{c|}{$\mathrm{X}^{2}$ values } & Probability \\
\hline Pokkali/ BR29 & $5.87^{* *}$ & 1.99 & $1.28^{* *}$ & 234 & $0.50-0.60$ \\
NonaBokra/ BR29 & $6.06^{* *}$ & $1.82^{* *}$ & $1.29 * *$ & 0.98 & $0.75-0.90$ \\
Nonasail / BR29 & $6.94^{* *}$ & $1.22 * *$ & 0.38 & $21.60 * *$ & $<0.01$ \\
Rajasail / BR29 & $6.74 * *$ & $1.09 * *$ & $-0.68 * *$ & 6.98 & $0.05-0.10$ \\
Binnatoa / BR29 & $6.52 * *$ & $1.36 * *$ & $-0.95 * *$ & $8.44 *$ & $0.05-0.10$ \\
Purbachi I BR29 & $6.92 * *$ & $0.78^{* *}$ & $-0.76 * *$ & 6.46 & $0.05-0.10$ \\
\hline
\end{tabular}

** Significant at $1 \%$ level of probability

The scaling test and the joint scaling test for the additive-dominance model using individual test for each of the crosses indicated absence of on-allelins interact in two crosses out of six. Henec, the model was extended to sixparameter model of Hayman (1958) to include digenic epistasis and estimated effects of $\mathrm{m}, \mathrm{d}, \mathrm{h}, \mathrm{i}, \mathrm{j}$, and 1 are presented in Table 6 .

Table 6. Gene effects for salinity tolerance scores in six parameter model in rice.

\begin{tabular}{l|c|c|c|c|c|c}
\hline \multicolumn{1}{c|}{ Cross } & Mean (m) & Additive (d) & Dominance (h) & $\begin{array}{c}\text { Additive } \mathrm{x} \\
\text { Additive (i) }\end{array}$ & $\begin{array}{c}\text { Additive } \mathrm{x} \\
\text { Dominance } \\
(\mathrm{i})\end{array}$ & $\begin{array}{c}\text { Diminance } \mathrm{x} \\
\text { Dominance } \\
(\mathrm{I})\end{array}$ \\
\hline $\begin{array}{l}\text { Pokkali/ } \\
\text { BR29 }\end{array}$ & $5.15 \pm 0.11^{* *}$ & $-1.70 \pm 0.33^{* *}$ & $-0.42 \pm 0.84$ & $0.86 \pm 0.79$ & $0.32 \pm 0.35$ & $-1.37 \pm 1.49$ \\
$\begin{array}{l}\text { Nonabokra/ } \\
\text { BR29 }\end{array}$ & $5.45 \pm 0.13^{* *}$ & $-1.74 \pm 0.33^{* *}-1.96 \pm 0.88^{*}$ & $-0.72 \pm 0.84$ & $0.09 \pm 0.35$ & $1.47 \pm 1.51$ \\
$\begin{array}{l}\text { Nonasail/ } \\
\text { BR29 }\end{array}$ & $7.36 \pm 0.11^{* *}$ & $-1.89 \pm 0.22^{* *}-0.95 \pm 0.67$ & $-1.06 \pm 0.63$ & -0.87 & $\pm 0.21 \pm 1.09$ \\
$\begin{array}{l}\text { Rajasail/ } \\
\text { BR29 }\end{array}$ & $6.36 \pm 0.11^{* *}$ & $-1.19 \pm 0.35^{* *}-0.67 \pm 0.86$ & $1.62 \pm 0.81^{*}$ & $-0.12 \pm 0.36$ & $-3.89 \pm .56^{*}$ \\
$\begin{array}{l}\text { Binnatoa/ } \\
\text { BR29 }\end{array}$ & $5.80 \pm 0.12$ & $-1.06 \pm 0.36^{* *} 1.39 \pm 0.91$ & $2.04 \pm 0.86^{*}$ & $0.32 \pm 0.37$ & $-2.29 \pm 1.62$ \\
$\begin{array}{l}\text { Purbachi/ } \\
\text { BR29 }\end{array}$ & $6.64 \pm 0.10^{* *}$ & $-0.14 \pm 0.35$ & $-2.20 \pm 0.88^{*}$ & $-1.36 \pm 0.81$ & $0.74 \pm 0.37 *$ & $1.99 \pm 1.59$ \\
\hline
\end{tabular}

* significant at $5 \%$ level $\quad * *$ Significant at $1 \%$ level 
In the cross Pokkali/BR29, additive component (d) was significant but other components are insignificant. Significant $d$ value indicates the higher contribution of additive component for salinity tolerance score and thereby inheritance of this character appeared simple. Insignificance i, j and 1 values indicate absence of epistasis.

In NonaBokra/BR29, additive (d) and dominance (h) effects were significant indicating both additive and non-additive gene actions ware operative for inheritance of this trait. There was no involvement of epistasis in this cross as shown by insignificant $\mathrm{i}, \mathrm{j}$ and 1 values.

In the cross Nonasail/BR29, inheritance of salinity tolerance was controlled by additive and additive $x$ dominance gene actions. In Rajasail/BR29, the salinity tolerance was controlled by additive gene action, and also by additive $\mathrm{x}$ additive and dominance $\mathrm{x}$ dominance type of epistasis. The salinity tolerance in the cross Binnatoa/BR29 was controlled by additive and additive $\times$ additive gene actions. Presence of interaction parameters (i, j, or i) along with additive component indicates the complex nature of the character. In Purhachi/BR29, this trait was controlled by dominance and additive $\mathrm{x}$ dominance gene actions indicating the greater contribution of dominance (h) on mean.

Tabel 7. Estimates of heritability (BS) for salinity tolerance score in six crosses of rice.

\begin{tabular}{lll}
\multicolumn{1}{c}{ Cross } & & Heritability (\%) \\
\hline Pokkali/BR29 & 54 & \\
Nonabokra?BR29 & 59 & \\
Nonasil/BR29 & 51 & \\
Rajasail/BR29 & 33 & \\
Binnatoa/BR29 & 49 & \\
Purbachi/BR29 & 34 & \\
\hline
\end{tabular}

The gene effect estimates in the six-parameter model showed that except Purbachi/BR29, the additive effects ware significant in all the crosses and the estimates of dominance ware significant only in the crosses NonaBokra/BR29 and Purhachi/BR29. This indicated the importance of additive gene actions in tie inheritance of salinity tolerance in rice. Jones (I 985) reported the importance of additive genetic variance in rice by observing salinity tolerance by tolerance ratio of root growth in $\mathrm{F}_{1} . \mathrm{F}_{2}$ and backcrosses.

The six- parameter model showed that non-allelic interaction effects additive dominance in the cross Nonasail/BR29, additive $\mathrm{x}$ additive and dominance dominance in Rajasail/BR29 and only additive $\mathrm{x}$ additive in the cross Binnatoa/BR29 contributed to the variation among the generation means. The nature of additive dominance gene action in the cross Nonasail/BR29 was partly indicated by the potence value of -0.11 which pointed out a small degree of partial dominance of salinity tolerance in this cross. Additive $\mathrm{x}$ additive and 
dominance $s$ dominate in Rjasaih/BR29 and additive $\mathrm{x}$ additive in Binnatoa/BR29 were indicated by their potence values of 0.90 and 0.48 that pointed out complete and partial dominance of salinity tolerance, respectively. Additive and non- allelic interaction effects of these three crosses contributed to non-additive situation among the generation means.

Mather and Jinks (1971) showed that the classification of interactions on the basis of the related magnitudes and signs of the estimates of the six parameters largely depends on the magnitude and signs of the estimates of $h$ and I. When $h$ and I are of the same signs, the interactions are mainly of a complementary or recessrc episiatitc kind, but classified as predominantly of a complementary type. When $\mathrm{h}$ and I are of opposite signs, the interactions are mainly of the duplicate dominant epistatic or recessive suppressor kind, and the interaction is classified as predominantly of a duplicate type. Based on this, the non-allelic interactions present in the crosses Nonasail/BR29, Rajasail/BR29 and Binnatow/BR29 can be classified as predominantly of a duplicate type.

The test for the additive-dominance model by scaling tests for each of the crosses indicated absence of non-allelic interaction in the crosses Pokkahi/BR29). NanaBokra/BR29 and Purbachi/BR29 (Table 4). However, in the six parameter model, Purbachi/BR29 showed significant additive $\mathrm{x}$ dominance $(\mathrm{j})$ effect and the interaction was predominantly of the duplicate type as indicated by the opposite sign of $\mathrm{h}$ and I estimates (Table 6). The reason for discrepancy in the cross Purbachi/BR29 might be due to significant dominance (h) effect.

In the estimation of the genetic parameters, non-allelic interactions were observed only in the crosses with moderately tolerant and susceptible parents. There was no evidence of non-allelic interactions in the crosses with tolerant and susceptible parents i.e., in Pokkali/BR29 and NonaBokra/BR29. Genes having additive effects contributed more in the inheritance of salinity tolerance in Pokkali/BR29, while NonaBokra/BR29 had predominantly additive and dominant gene actions and there was no involvement of epistasis. Hence, Pokkali/BR29 was the best cross since it offered highest scope for response to selection due to predominance of additive gene action compared to other crosses. While NonaBolra/BR29 offered better respones to selection due to predominance of additive and dominance gene actions and no involvement of epistasis. The additive effects could facilitate fixation of the combination of genes and therefore, selection for salinity tolerance in these crosses would give better response. According to Comstoek et al. (1949), use of reciprocal recurrent selection has been suggested to improve the trait on the cross NanaBokra/BR29 as both additive and non-additive gene effects arc involved in the expression of the trait. The significant additive and additive $\times$ additive type of interaction effects and significant additive and additive $\times$ dominance effects were also 
considerable in the crosses Binnatoa BR29 and Nonasail/BR29, respectively. These effects may facilitate fixation of the desirable combination of genes. However, the presence of duplicate epistasis in this trait can hinder progress and make it difficult to fix genotypes at a high level of manifestation. According to Shamsuddin et al. (1994), duplicate epistasis may restrict the expression of a trait in early segreating generations. The selection in early generations would not be effective for want of fixable components of variation. Such gene effects can, however, be exploited by intermating the selected segregants and delaying the selection to the advanced generations. The other possibilities could be diallel selective mating system as proposed by Jensen (1970) or the recurrent selection procedures (Singh and Power, 1990).

Although there was additive $\times$ additive and dominance $\times$ dominance epistasis in Rajasaili/BR29, but there was also appreciable amount of auditive gene action.

Therefore, this cross may give response to selection for salinity to tolerance but predominance of epistasis bar the trait indicates that good response to selection is difficult.

\section{Heritability estimates}

Estimates of broad-sense heritability for salinity tolerance score were computed in $F_{2}$ generation. The heritability for salinity tolerance score was very low to medium (Table 7). The average estimate of heritability for the six crosses was 46.7\% Heritability was very low in the crosses Rajasail/BR29 and Purbachi/BR29. These values might have been due to small difference in parental values, the low to moderate levels of heritability indicated that a large proportion of the phenotypic variance was due to non-genetic effects. The estimates of gene effects in a parameter model (Table 6) indicated the duplicate relations between non-allelic genes in four crosses (Nonasail/BR29, Rajasail/BR29, Binnatoa/RR29 and Purbachi/BR29). The duplicate relations between genes were reported to reduce $F_{2}$ variance to a level lower than that, which would be obtained in the absence of such interaction (Mathe and Jinks, 1971). The possible reduction of $F_{2}$ variance due to the duplicate relation between genes might have another factor that affected the low heritability values. The moderately high heritability values in t o crosses Pokkali/BR29 and NonaBokra/BR29 could partly be explained by their estimates of gene effects in a six parameter model where the significant effects were on additive (Pokkali/BR29) and additive and dominance (NonaBokra BR29) effects. Based on these estimates, the additive effects seemed to have given more contributions to the genetic variance, Gregorio and Senadhira (1993) also observed low to moderate heritability in rice. As heritability of the trait was low to moderate, the breeding population must be large and selection for tolerance must be exercised in later generations under controlled cconditions. 


\section{References}

Allard, R.W. 1900. Principles of Plant Breeding. Pp. 105-107. John Wiley and Sons. Inc. NY.

Cavalli, L.L. 1952. An analysis of linkage in quantitatie inheritance. Quantitative inheritance (ed.E.C.R. Rieve and Waddiingon, C.H.), HMSO, London, pp. 144.

Comstock, R.E., H.F. Robinson and P.H. Harvey. 1949. A breeding procedure designed to make maximum use of both general and specific combining ability. Agron. J. 41: 360-367.

Gill, K.S. and O.S. Singh. 1995. Studies on the growth, ionic composition and yield characters associated with salt tolerance in rice. J. Potassium Res. I : I 6-175

Greenland. D.J. (1984). Exploited plants: rice. Biologist 31:291-295.

Gregorio. G.B. and D. Senadhira. 1993. Genetic analysis of salinity tolerance in rice. Theor. AppI. Genet. 86: 333-338.

Gregorio, G.B., D. Senadhira, and R.1. Mendoza, 1997. Screening rice fbr salinity tolerance. IRRI Discussion paper series no.22. BRRI. Philippines. pp. 1-30.

Hayman, B. 1. 1958. the separation of epislasis froni additive dominance variation in generation means. Heredity 12: 371-390.

Jensen, N.E. 1970. Diallel selective mating system or cereal breeding. Crop Sci. 10: 629635.

Jones, M.P. 1985. Genetics analysis of salt tolerance ill mangrove swamp rice. In Rice Genetics 1 pp. 411-422. IRRI, Philippines.

Lee. KS. and D. Senadhira. 1996. Salinit tolerance in. Japonica rice. SABRAO 28:1 1-17.

Mather, K. and J.L. Jinks, 1971. Biometrical Genetics. Chapman and Hall Ltd. London.

Shamsuddin, A.K.M., Rahman, L., Islam, M.A. amd Miah, M.A.J. (1994). Selection for grain yield and yield components in spring wheat. Bang. J. PI. Breed. Genet. 7: 1-5.

Singh, S. and. I.S. Power. 1990. An appraisal of selection methods in self fertilized crops. In: "Trends in Crop Improvement. R.K. Pehl and N. Meharchandani (eds), pp. 17-26. India. 